\title{
INVASION OF SAVANNAS BY PROSOPIS TREES IN EASTERN AFRICA: EXPLORING THEIR IMPACTS ON LULC DYNAMICS, LIVELIHOODS AND IMPLICATIONS ON SOIL ORGANIC CARBON STOCKS
}

\author{
P. R. Mbaabu ${ }^{1,2,3^{*}}$, U. Schaffner ${ }^{4}$, S. Eckert ${ }^{5,6}$ \\ ${ }^{1}$ Faculty of Humanities and Social Sciences, Chuka University, P.O. Box 109-60400, Chuka, Kenya - (purityrima@ gmail.com). \\ ${ }^{2}$ Kenya Forestry Research Institute (KEFRI), Baringo Sub-Centre, P.O. Box 57-30403, Marigat, Kenya. \\ ${ }^{3}$ Institute for Climate Change and Adaptation, University of Nairobi, P.O. Box 30197-00100, GPO, Nairobi, Kenya. \\ ${ }^{4}$ CABI, Rue des Grillons 1, 2800 Delémont, Switzerland - (u.schaffner@ cabi.org). \\ ${ }^{5}$ Centre for Development and Environment (CDE), University of Bern, Mittelstrasse 43, CH-3012 Bern, Switzerland - \\ (sandra.eckert@unibe.ch). \\ ${ }^{6}$ Institute of Geography, University of Bern, Hallerstrasse 10, CH-3012 Bern, Switzerland.
}

*Author to whom correspondence should be addressed.

KEY WORDS: Prosopis invasion; grassland restoration; Landsat; random forest; Land Use Land Cover Change; Soil Organic Carbon; climate change mitigation; Kenya.

\begin{abstract}
Trees of the genus Prosopis from the Americas, were introduced in Eastern Africa in the 1970s to mitigate land degradation and its associated disservices. However, over time these trees have spread and invaded valuable grasslands and croplands and consequently led to significant land use and land cover (LULC) changes and livelihood stress. Early detection of invasive species is essential for formulating effective management strategies to prevent further spread into non-invaded lands and for monitoring the outcome of management interventions. We mapped the spatio-temporal evolution and dynamics of Prosopis invasion, its impacts on LULC and livelihoods in Baringo, Kenya by applying a Random Forest classifier on Landsat satellite data over seven-year intervals from 1988 2016. We then linked the LULC changes to soil organic carbon (SOC) stocks that we had measured for the different LULCs and also to socio-economic data on annual costs of clearing Prosopis from farmlands. By 2016, Prosopis had invaded 18,792 ha of land, spreading at a rate of $640 \mathrm{ha} / \mathrm{yr}$, while all other land uses and land cover declined, each by over $40 \%$ of its original coverage in 1988. Through LULC specific SOC measurements, and relating the changes to annual costs of clearing Prosopis, we found that Prosopis removal and restoration to grassland is more effective for climate change mitigation compared to Prosopis "cultivation" while also avoiding trade-offs with other ecosystem services and livelihoods. Therefore, future management of this species in Kenya and Eastern Africa should be based on a more collaborative and integrated approach.
\end{abstract}

\section{INTRODUCTION}

Grasslands are the dominant natural cover in terrestrial tropics and comprise about $20 \%$ of the global land area (Parr et al., 2014; Scholes \& Archer, 1997). They have significant contributions to environment, economies and provide a host of cultural benefits (Parr et al., 2014). For instance, they are home to a substantial diversity of plants and animals, directly support livelihoods of about one-fifth of the global population through provision of food, grazing, fuel wood and medicinal value plants. Moreover, they account for about $30 \%$ of global total terrestrial net primary productivity, provide other ecosystem services including forage for livestock, tourism and the regulation and storage of water flows (White et al., 2000). Additionally, they store approximately $15 \%$ of global terrestrial carbon (Parr et al., 2014), hence play a key role in global carbon cycle (Grace et al., 2006).

Despite the importance of these ecosystems, tropical savannas are also arguably the most fragile ecosystems globally. They face multifaceted vulnerabilities ranging from anthropogenic encroachment, climate change and alien plant species among others. Furthermore, despite their fragility and the widely recognized role in supporting livelihoods of millions of people particularly in Sub-Saharan Africa, they have in recent years become targets for woody tree expansion for climate change mitigation projects for instance under the Clean Development Mechanism (CDM) and Reducing Emissions from Deforestation and Forest Degradation (REDD+) programs (Parr et al., 2014). Woody alien invasive plants have been intentionally introduced in many arid and semi-arid lands as they provide some goods and services to the rural communities. In the early 1980s, trees of the genus Prosopis which are native to Latin America were introduced in Baringo, a tropical semiarid zone in Kenya to mitigate land degradation and alleviate firewood shortage (Kariuki, 1993; Schwartzstein, 2019). Prosopis spp. or mesquite, are perennial, nitrogen-fixing singlecanopy trees or multi-stemmed shrubs tolerant to arid conditions (Andersson, 2005). Globally, these species are among the most damaging invasive species, which has led to their inclusion in the World Conservation Unions list of 100 worst invasive alien species (Lowe et al., 2000). They are regarded as noxious invaders considerably impacting biodiversity, ecosystems services and economies, particularly in their invasive ranges (Shackleton et al., 2014). 
Although the species was initially appreciated for its fast proliferation and ability to grow even in severely degraded landscapes where regeneration of native vegetation proved difficult owing to persistent ecosystem disturbances such as overgrazing (Doran et al., 1979), over time these trees have spread and invaded valuable grasslands and croplands. They have become unmanageable due to fast proliferation and ability to survive cutting by coppicing (Mwangi \& Swallow, 2005). Consequently this has led to significant land use and land cover (LULC) changes and livelihood stress (Mbaabu et al., 2019). Although LULC changes primarily driven by human activities such as deforestation, land clearing, overgrazing and climate change are present in most biomes, tropical savannas face unique, emerging additional threats that arise from woody alien tree species encroachment such as the case of Prosopis juliflora in Eastern Africa. Therefore, assessing their spatial spread and rate of increase is key for understanding their impacts on various ecosystem services and human well-being.

On the basis of three separate, yet interlinked studies in the same study area (Bekele et al., 2018; Mbaabu et al., 2019, 2020), this conference paper aims to provide a deeper insight on the impacts of alien invasive Prosopis encroachment into savannas on selected ecosystem service (soil organic carbon) and livelihoods. Soils account for the largest share of terrestrial carbon containing more carbon than the atmosphere and vegetation combined (FAO, 2017). Moreover, they host a relatively stable carbon stock, compared to the more transitory carbon stocks in above-ground vegetation biomass (Doney et al., 2006). As such, soil organic carbon was considered as an important parameter for assessing impact of Prosopis invasion in this study because carbon sequestration is an important ecosystem service (Nelson et al., 2008). We use monetary cost of clearing and managing Prosopis invaded farmlands and loss of pasture for livestock as proxies for assessing impact of Prosopis invasion on rural livelihoods. Invasion of farmlands limits food production while loss of grazing land reduces wealth accumulation potential since livestock production is a key source of livelihood for many pastoralists and agro-pastoralists in Sub-Saharan Africa (Doran et al., 1979). We also aim to show that synergistic use of spatial remote sensing data, socioeconomic and other field-based measurements of spatial phenomena can contribute to a better analysis and understanding of complex ecological and societal problems.

\section{METHODS}

Early detection and mapping of invasive species is essential for formulating effective management strategies to prevent further spread into non-invaded lands and for monitoring the outcome of management interventions. Remote Sensing provides costefficient means to assess the distribution of alien plant species and monitor their spread even in inaccessible areas. Reliable estimates of Prosopis invasion needed for informing policy decisions were lacking for Kenya.

We used Landsat time-series data acquired from 1988 - 2016 and mapped how this tree has spread from original plantations and the implications of its spread on other land uses/cover, as well as livelihoods. Data from Landsat sensor were preferred because these data have been captured over a long historical period, in a consistent manner and its moderate spatial resolution of $(30 \mathrm{~m})$ is considered sufficient for vegetation mapping and monitoring. Moreover, many other studies have utilized Landsat data to assess spatio-temporal Prosopis distribution in Africa (Kyuma et al., 2016; Shiferaw et al., 2019; Van den Berg, 2010).
We collected reference points distributed across the LULC types in the study area. For historical imagery, reference samples were collected by visual interpretation of Landsat imagery and Very High Resolution satellite imagery on Google Earth Pro, in supplementation with local expert historical knowledge. We performed a LULC classification using random forest classifier in R statistical software version 3.4.4 (Breiman, 2001; R Core Team, 2018), for 5 time-steps at 7 year intervals from 1988-2016. We related the LULC changes to Soil Organic Carbon (SOC) stocks that we had measured for the different LULC types in the same study area (Mbaabu et al., 2020). Soil samples for SOC analysis were collected from $15 \times 15 \mathrm{~m}$ field plots representing LULC such as pristine grasslands, degraded grasslands, restored grasslands and Prosopis invaded plots, at soil sampling depths of up to $1 \mathrm{~m}$ (Mbaabu et al., 2020). SOC content in field soil samples was determined using colorimetric method (Anderson \& Ingram, 1994). Further, using the average willingness to pay for clearing Prosopis invaded lands, that was estimated in a separate study within the study area, we computed the cost of clearing Prosopis from invaded farmlands. The costs of manual Prosopis removal from invaded lands, which was expressed as average willingness to pay was determined based on a choice experiment conducted among 250 households in Baringo (Bekele et al., 2018).

\section{RESULTS AND DISCUSSIONS}

We found that between 1988 and 2016 Prosopis increased by $2031 \%$, while grasslands, native vegetation and croplands decreased by $86 \%, 42 \%$ and $47 \%$ respectively (Mbaabu et al., 2019) (Figure 1). Prosopis invasion alone directly contributed to over $30 \%$ of these negative changes, implying that Prosopis invasion is a key driver of the observed LULC changes in Baringo, which is severely affecting agro-pastoral livelihoods. Prosopis increased by about $640 \mathrm{ha} / \mathrm{yr}$, confirming that it is an aggressive invader as observed in other studies in Africa (Ndhlovu et al., 2016; Wakie et al., 2016). This rapid spread is attributed to: a) its massive seed production, b) presence of effective seed dispersal agents in the study area e.g (livestock and wildlife) and dispersal pathways (rivers and roads), and c) favourable climatic conditions. With this rapid increase, the local communities have been losing grasslands and croplands at an alarming rate, which are important land-cover /uses that form key part of their livelihood support system.

We estimated that about 2948 ha of cropland was invaded by Prosopis between 1988-2016, of which, approx. 891 ha was cleared off Prosopis and restored to farmland over the same period (Mbaabu et al., 2019). Using the estimated costs of manual Prosopis removal from farmlands ( USD 265.61 per ha per annum) (Eschen et al., 2021), this translates to a clearing cost of USD 236,658.51. The net loss of farmland to Prosopis as at 2016 was about 2057 ha, which would require a budget of approx. USD 546,359.77 to restore the land back to productive farmland. This scenario presents an additional livelihood strain to the already marginalized rural communities in Baringo. Many households cannot afford these additional costs of managing their farmlands hence abandon the invaded lands creating a further loss in livelihood.

We further found that approx. 2675 ha of grassland (which represents $37 \%$ of grasslands present in the study area prior to Prosopis introduction) have been lost to Prosopis invasion between 1988-2016. The economic sustenance of rural Baringo communities is heavily dependent on livestock keeping. With 
the shrinking of available grazing land, the lands carrying capacity for livestock productivity is further limited. Moreover, this is likely to escalate inter-community violence which is already rampant in the area owing to competition for scarce resources such as pasture and water (Relief Web, 2017). Prosopis is known to abstract significant amounts of ground water (Dzikiti et al., 2013, 2017; Fourie et al., n.d.) and may contribute to drying up of ground water recharge systems which may further exacerbate the prevailing problems.

Owing to the decrease in available grazing land by 2005 , the community was already adversely pressed by Prosopis invasion, a predicament they blamed on the government of Kenya (GoK) and the Food and Agriculture Organization of the United Nations (FAO) who were responsible for Prosopis introduction in Baringo (Little, 2019). This prompted a legal suit against the Kenyan government by the local pastoralist community(Little, 2019). The government responded by launching a Prosopis sensitization programme and communitywide training on Prosopis management through manual or physical removal and subsequently reseeding the cleared land with native perennial grasses. This practice was gradually adopted by pastoralists as it enhanced fodder availability and also provided additional income through commercial grass seed production (Lugusa et al., 2016). Additionally, communities were trained on charcoal production using the harvested Prosopis wood, leading to the popular terminology 'management by utilization' in the context of Prosopis management in the region. However, although this practice has been widely promoted for over a decade with expectations that it would prevent further Prosopis spread our spatial LULC dynamics analyses provide evidence that this strategy has not been effective in halting or slowing down Prosopis spread (Mbaabu et al., 2019).

Through our LULC specific SOC measurements, we found that Prosopis removal and restoration of grasslands is more effective for climate change mitigation compared to Prosopis "cultivation" while also avoiding trade-offs with other ecosystem services (Mbaabu et al., 2020). Moreover, a recent study by Eschen et al.(Eschen et al., 2021) has revealed that clearing Prosopis and restoring the land to native grassland has additional significant economic benefits to the rural Baringo communities, hence providing more sustainable livelihoods.

Prosopis invasion into grasslands led to loss of 30,067 tonnes of SOC, while restoring the currently Prosopis invaded and degraded grassland have the potential to sequester 257,835 tonnes of SOC over the next 30 years (Table 1). Although Prosopis invasion into previously degraded land also increases SOC, invasion of pristine or restored grasslands leads to loss of SOC (Eschen et al., 2021; Mbaabu et al., 2020). Further, invasion comes at a high cost on the ecosystem and livelihoods because the restoration of grassland-characteristic biodiversity and ecosystem services may be blocked.

\section{CONCLUSIONS}

Expansion of woody trees including alien species is an emerging issue in dryland ecosystems. In recent years, this practice has even been put forward as a legitimate climate change mitigation strategy. This approach has been met with criticisms from the scientific community often because of the wide range of ecological, social and economic implications of tree expansion, particularly alien species in arid and semi-arid lands. We explored to elucidate the interlinked impacts of Prosopis invasion on LULC changes, ecosystem services and rural livelihoods in a savanna grassland ecosystem in Eastern Africa. We conclude that Prosopis is a key driver of LULC changes in the study area, significantly limits the opportunities for ecosystem service delivery and has adverse effects on rural livelihoods. On the contrary, restoration of degraded lands provides more opportunities for climate change mitigation and socio-economic livelihood sustenance.

Based on these findings, we suggest that future management of this species in Kenya and Eastern Africa should be based on a more collaborative and integrated approach. Our results feed into the first ever National Prosopis Strategy for Kenya and will be taken up by policy makers and land use managers to guide future management of degraded lands as well as Prosopis invasions. 


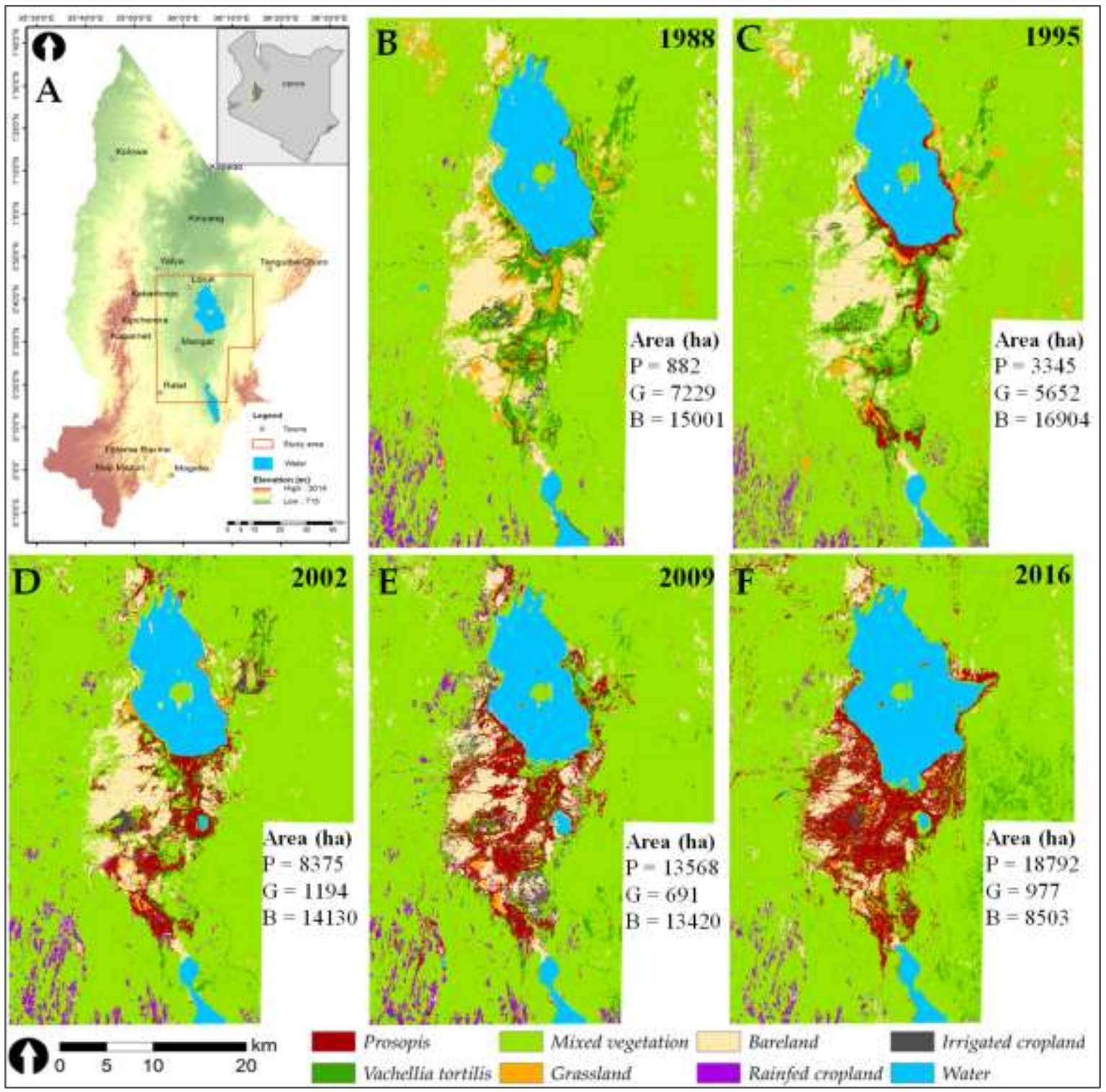

Figure 1. Overview map (A) and LULC maps (B-F) of Marigat subregion, Baringo County, Kenya, for the years 1988, 1995, 2002, 2009, and 2016. The letters P, G and B represent key land cover classes: Prosopis, grassland (pristine \& restored) and bareland (degraded grassland), with their respective area coverage in hectares at each time interval. The overview map shows the topography, towns and lakes. The red boundary zone is the extent of the study area. 


\begin{tabular}{|c|c|c|c|c|c|}
\hline Category & $\begin{array}{c}\text { Area } \\
\text { (ha) }\end{array}$ & $\begin{array}{c}\text { Current SOC } \\
\text { under Prosopis } \\
\text { invasion } \\
\left.\text { (t C ha' }^{-1}\right)\end{array}$ & $\begin{array}{l}\text { Potential SOC under } \\
\text { grassland restoration } \\
\text { over } 30 \text { years } \\
\left(\text { t } \mathrm{C} \mathrm{ha} \text { h }^{-1}\right)\end{array}$ & 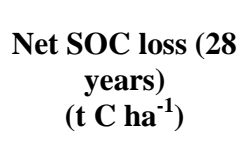 & $\begin{array}{l}\text { Potential } \\
\text { SOC gain via } \\
\text { restoration } \\
\left(\mathrm{t} \mathbf{C} \text { ha }^{-1}\right)\end{array}$ \\
\hline $\begin{array}{l}\text { Pristine grassland lost to } \\
\text { Prosopis invasion } \\
\text { (1988-2016) }\end{array}$ & 2675 & 103041.00 & 119519.00 & -30067.00 & 16478.00 \\
\hline $\begin{array}{l}\text { Prosopis invaded land } \\
(1988-2016)\end{array}$ & 18792 & 723867.84 & 839626.56 & $\mathrm{n} / \mathrm{a}$ & 115758.70 \\
\hline $\begin{array}{l}\text { Degraded grassland / } \\
\text { bareland }\end{array}$ & 8503 & $\mathrm{n} / \mathrm{a}$ & 111899.48 & $\mathrm{n} / \mathrm{a}$ & 111899.48 \\
\hline $\begin{array}{l}\text { Pristine grassland lost to } \\
\text { degraded grassland / } \\
\text { bareland (1988-2016) }\end{array}$ & 1041 & $\mathrm{n} / \mathrm{a}$ & 13699.44 & -18987.67 & 13699.48 \\
\hline $\begin{array}{l}\text { Potential SOC storage } \\
\text { by grassland } \\
\text { restoration }\end{array}$ & 31011 & $\mathbf{n} / \mathbf{a}$ & $\mathbf{n} / \mathbf{a}$ & $\mathbf{n} / \mathbf{a}$ & 257835.62 \\
\hline
\end{tabular}

Table 1. Potential soil organic carbon storage through grassland restoration of currently Prosopis invaded and degraded land over the next 30 years.

\section{REFERENCES}

Anderson, J. M., \& Ingram, J. S. I., 1994. Tropical Soil Biology and Fertility: A Handbook of Methods. The Journal of Ecology, 78(2), 547. https://doi.org/10.2307/2261129

Andersson, S., 2005. Spread of the introduced tree species Prosopis juliflora (Sw.) DC in the Lake Baringo area, Kenya [Thesis]. Swedish University of Agricultural Sciences.

Bekele, K., Haji, J., Legesse, B., \& Schaffner, U., 2018. Economic impacts of Prosopis spp. invasions on dryland ecosystem services in Ethiopia and Kenya: Evidence from choice experimental data. Journal of Arid Environments, 158, 9-18. https://doi.org/10.1016/j.jaridenv.2018.07.001

Breiman, L., 2001. Classification and regression based on a forest of trees using random in-puts, based on Breiman (2001. Machine Learning, 45(1), 5-32. https://doi.org/10.1023/A:1010933404324

Doney, S. C., Lindsay, K., Fung, I., \& John, J., 2006. Natural Variability in a Stable, 1000-Yr Global Coupled ClimateCarbon Cycle Simulation. Journal of Climate, 19(13), 30333054. https://doi.org/10.1175/JCLI3783.1

Doran, M. H., Low, A. R. C., \& Kemp, R. L., 1979. Cattle as a Store of Wealth in Swaziland: Implications for Livestock Development and Overgrazing in Eastern and Southern Africa. American Journal of Agricultural Economics, 61(1), 41. https://doi.org/10.2307/1239498
Dzikiti, S., Ntshidi, Z., Le Maitre, D. C., Bugan, R. D. H., Mazvimavi, D., Schachtschneider, K., Jovanovic, N. Z., \& Pienaar, H. H., 2017. Assessing water use by Prosopis invasions and Vachellia karroo trees: Implications for groundwater recovery following alien plant removal in an arid catchment in South Africa. Forest Ecology and Management, 398, 153-163. https://doi.org/10.1016/j.foreco.2017.05.009

Dzikiti, S., Schachtschneider, K., Naiken, V., Gush, M., Moses, G., \& Le Maitre, D. C., 2013. Water relations and the effects of clearing invasive Prosopis trees on groundwater in an arid environment in the Northern Cape, South Africa. Journal of Arid Environments, 90, 103-113. https://doi.org/10.1016/j.jaridenv.2012.10.015

Eschen, R., Bekele, K., Mbaabu, P. R., Kilawe, C., \& Eckert, S., 2021. Prosopis juliflora (Sw.) DC. management and grassland restoration in Baringo County, Kenya: Opportunities for soil carbon sequestration and local livelihoods. Journal of Applied Ecology. https://doi.org/10.1111/1365-2664.13854

FAO, 2017. Soil Organic Carbon: the hidden potentail (eds. Liesl, W., Viridiana, A., Rainer, B.\& Ronald,V.) ISBN 978-925-109681-9.

Fourie, F., Mbatha, K., Verster, H., \& Dyk, G. V., n.d. The Effect of Vegetation (Prosopis Sp.) on Groundwater levels in Rugseer River, Kenhardt, South Africa. 8.

Grace, J., Jose, J. S., Meir, P., Miranda, H. S., \& Montes, R. A., 2006. Productivity and carbon fluxes of tropical savannas. 
Journal of Biogeography, 33(3), https://doi.org/10.1111/j.1365-2699.2005.01448.x

$387-400$.

Kariuki, P., 1993. A social forestry project in Baringo, Kenya: A critical analysis [Master Thesis, University of Queensland: Brisbane, Australia].

Kyuma, R. K., Wahome, R. G., Kinama, J. M., \& V, O. W., 2016. Temporal relationship between climate variability, Prosopis juliflora invasion and livestock numbers in the drylands of Magadi, Kenya. African Journal of Environmental Science and Technology, 10(4), 129-140. https://doi.org/10.5897/AJEST2015.2034

Little, P. D., 2019. When "Green" Equals Thorny and Mean: The Politics and Costs of an Environmental Experiment in East Africa. African Studies Review, 62(3), 132-163. https://doi.org/10.1017/asr.2019.41

Lowe, S., Browne, M., Boudjelas, S., \& de poorter, M., 2000. 100 of the World's Worst Invasive Alien Species: A selection from the Global Invasive Species Database. Invasive Species Specialist Group (ISSG) a Specialist Group of the Species Survival Commission (SSC) of the World Conservation Union $(I U C N), 12$

Lugusa, K. O., Wasonga, O. V., Elhadi, Y. A., \& Crane, T. A., 2016. Value chain analysis of grass seeds in the drylands of Baringo County, Kenya: A producers' perspective. Pastoralism, 6(1), 6. https://doi.org/10.1186/s13570-016-0053-1

Mbaabu, P. R., Ng, W.-T., Schaffner, U., Gichaba, M., Olago, D., Choge, S., Oriaso, S., \& Eckert, S., 2019. Spatial Evolution of Prosopis Invasion and its Effects on LULC and Livelihoods in Baringo, Kenya. Remote Sensing, 11(10), 1217. https://doi.org/10.3390/rs11101217

Mbaabu, P. R., Olago, D., Gichaba, M., Eckert, S., Eschen, R., Oriaso, S., Choge, S. K., Linders, T. E. W., \& Schaffner, U., 2020. Restoration of degraded grasslands, but not invasion by Prosopis juliflora, avoids trade-offs between climate change mitigation and other ecosystem services. Scientific Reports, 10(1). https://doi.org/10.1038/s41598-020-77126-7

Mwangi, E., \& Swallow, B., 2005. Invasion of Prosopis juliflora and local livelihoods: Case study from the Lake Baringo Area of Kenya. World Agroforestry Centre.

Ndhlovu, T., Milton, S. J., \& Esler, K. J., 2016. Effect of Prosopis (mesquite) invasion and clearing on vegetation cover in semi-arid Nama Karoo rangeland, South Africa AU Ndhlovu, Thabisisani. African Journal of Range \& Forage Science, 33(1), 11-19. https://doi.org/10.2989/10220119.2015.1036460
Nelson, E., Polasky, S., Lewis, D. J., Plantinga, A. J., Lonsdorf, E., White, D., Bael, D., \& Lawler, J. J., 2008. Efficiency of incentives to jointly increase carbon sequestration and species conservation on a landscape. Proceedings of the National Academy of Sciences, 105(28), 9471. https://doi.org/10.1073/pnas.0706178105

Parr, C. L., Lehmann, C. E. R., Bond, W. J., Hoffmann, W. A., \& Andersen, A. N., 2014. Tropical grassy biomes: Misunderstood, neglected, and under threat. 29(4).

R Core Team., 2018. $R$ : A language and environment for statistical computing. R Foundation for Statistical Computing.

Relief Web., 2017. Baringo residents struggle with drought and conflict over resources.

Scholes, R., \& Archer, S., 1997. Tree-grass interactions in Savannas. Annual Review of Ecology and Systematics, 28, 517 544.

Schwartzstein, P., 2019. An invasive, thorny tree is taking over Africa-Can it be stopped? An Invasive, Thorny Tree Is Taking over Africa-Can It Be Stopped?

Shackleton, R. T., Le Maitre, D. C., Pasiecznik, N. M., \& Richardson, D. M., 2014. Prosopis: A global assessment of the biogeography, benefits, impacts and management of one of the world's worst woody invasive plant taxa. AoB PLANTS, 6, plu027. https://doi.org/10.1093/aobpla/plu027

Shiferaw, H., Schaffner, U., Bewket, W., Alamirew, T., Zeleke, G., Teketay, D., \& Eckert, S., 2019. Modelling the current fractional cover of an invasive alien plant and drivers of its invasion in a dryland ecosystem. Scientific Reports, 9(1), 1576. https://doi.org/10.1038/s41598-018-36587-7

Van den Berg, E. C., 2010. Detection, quantification and monitoring Prosopis spp. In the Northern Cape Province of South Africa using remote sensing and GIS/EC van den Berg [North-West University]. http://dspace.nwu.ac.za/handle/10394/4377

Wakie, T. T., Laituri, M., \& Evangelista, P. H., 2016. Assessing the distribution and impacts of Prosopis juliflora through participatory approaches. Applied Geography, 66, 132-143. https://doi.org/10.1016/j.apgeog.2015.11.017

White, R. P., Murray, S., \& Rohweder, M., 2000. Pilot analysis of global ecosystems: Grassland ecosystems. World Resources Institute. 